\title{
The Ore Grade and Depth Influence on Copper Energy Inputs
}

\author{
R. H. E. M. Koppelaar ${ }^{1,2}$ (D) H. Koppelaar ${ }^{3}$
}

Received: 15 March 2016/ Accepted: 12 November 2016/Published online: 22 November 2016

(c) The Author(s) 2016. This article is published with open access at Springerlink.com

\begin{abstract}
The study evaluated implications of different ore grades and mine-depth on the energy inputs to extract and process copper. Based on a 191 value dataset from 28 copper mining operations, seven model equations explaining operational energy costs were statistically evaluated. Energy costs for copper mines with leaching operations were not found to be significantly affected by ore grades nor mine-depth as all tested equations were rejected in the analysis. In case of mines with milling/ flotation operations, a significant relation was established $\left(p<0.000, R^{2}=0.63\right.$ for surface mines and $R^{2}=0.84$ for underground mines) which was found to be: energy cost is log-linearly dependent on depth plus the reciprocal of ore grade. On the basis of the equation, an ore grade of $0.5,0.4$ and $0.3 \%$ at $300 \mathrm{~m}$ of depth results in an energy cost of 60 , 127 and $447 \mathrm{MJ} / \mathrm{kg}$ to obtain a 30\%+ copper concentrate from underground mines, and 52, 95 and $255 \mathrm{MJ} / \mathrm{kg}$ for surface mines, respectively. Energy costs are found to accelerate significantly below the $0.5 \%$ ore grade level, which can be interpreted as a biophysical barrier below
\end{abstract}

Electronic supplementary material The online version of this article (doi:10.1007/s41247-016-0012-x) contains supplementary material, which is available to authorized users.

R. H. E. M. Koppelaar

r.koppelaar12@imperial.ac.uk

1 Centre for Environmental Policy, Faculty of Natural Science, Imperial College London, South Kensington Campus, London SW7 2AZ, UK

2 Institute for Integrated Economic Research, The Broadway, London W5 2NR, UK

3 Faculty of Electrical Engineering, Mathematics and Computer Science, Delft University of Technology, Mekelweg 4, 2628 CD Delft, The Netherlands which mining plus milling/flotation becomes increasingly challenging under current efficiency. In splitting out energy use into diesel and electricity, the study found both impacted by decreasing ore grades, but only electricity usage to be substantially influenced by mine-depth. Depth impacts were established as a $7 \%$ increase in electricity costs per $100 \mathrm{~m}$ and compounded by ore grades.

Keywords Copper mining - Ore grade $\cdot$ Mining depth Energy inputs · Production costs

\section{Introduction}

The element copper is vital to industrial society as copper is the second-best-known conductor of electricity, and has low corrodibility and large ductility (Emsley 2001). Copper has become a key material in the transport of electricity from power stations to industry and households and in machinery and electronic devices. Where in the year 1900 world copper production amounted to 0.5 million metric tonnes per year, it has risen to an estimated 18.7 million tonnes in the year 2015 (USGS 2014; Brininstool 2016). The prominence of copper has been enabled by significant reductions in extraction and concentrating costs since the early twentieth century, due to many technological advances and concentrating efficiency improvements, which have staved off price effects of the depletion of higher ore grade resources. These impacts can be exemplified by the broad simplified trends in inflation adjusted US copper market prices in the twentieth century (USGS 2014), with continued lower prices despite a decline from an average $2 \%$ to a $0.8 \%$ ore grade across the century (Mudd 2009). To highlight, the copper price is a complex variable as influenced by various factors including the 
demand-supply balance, underlying technologies, ore grades, investment and operational input costs, and hence, the following trends are highly simplified:

- The price at the start of the twentieth century was 8000 USD per metric ton in 2013 USD and declined to a level of 4200 USD at the early 1920s, influenced by the introduction of flotation techniques and economy of scale effects of larger mines and concentrating units impacted cost levels (Fuerstenau et al. 2007).

- The US copper price remained relatively stable from the 1920s to the 1940s around 4000 USD per metric ton, after which it began to increase up the mid-1970s, to a new price peak around 6800 USD per metric ton, possibly influenced by declining ore grades and increasing oil energy input costs.

- After the mid-1970s, the price declined up to the year 2001, with the lowest prices in recent history around 2350 USD per ton in the year 1999, possibly influenced by a combination of oil price declines, shifts from oil to electricity inputs, and because hitherto previously inaccessible low ore grade waste tailings became exploitable via heap leaching and solvent extractionelectrowinning (SX-EW), (Pitt and Wadsworth 1980; US Congress-Office of Technology Assessment 1988).

In the twenty-first century, copper prices quadrupled to a peak of 9270 USD in 2011 after which the price has declined to 6000 USD in 2015 (Brininstool 2016). The price increase has resulted in growing concerns on the availability and long-term affordability of copper resources, as signally by continued ore grade declines to $0.76 \%$ by 2014 (Mudd et al. 2013; CODELCO 2015). Concerns are further fueled because economically available reserves, as influenced by ore grades and depth among other factors, are typically limited to a few decades into the future, and as such stocks need to be replenished from known or undiscovered resources to enable production in the medium to long term (Mudd et al. 2013). In reaction to concerns, opposite views have been voiced of an abundant and available copper resource base stemming from technologyoriented perspectives (Tilton and Lagos 2007). Such wideranging perspectives over depletion-affordability concerns versus price-technology perspectives are not new and are also found in the literature of the 1970-1980s (Barnett 1979; Hall et al. 1986).

At a physical variable level, there is uncertainty whether changes in low ore grades and mining depth-among other factors-matter for the future of copper mining, especially given their influence on the energy costs of mining. These variables may not be as relevant, if lower ore grades and depth can be overcome by technological improvements and energy efficiency. The question is how the dynamics of technological change, extraction inputs and costs, and price and industry changes will be altered in the future (Bardi 2013). This issue has implications for decisions related to deciding over copper or aluminum in electricity transmission and distribution grids (Layton et al. 2015), the profitability of investment in copper mining relative to increasing copper recycling as an alternative (Kerr 2014), cost implications for wind energy technologies (Harmsen et al. 2013), the relevance of the local electricity infrastructure and its costs for mine investment, and energy infrastructure planning for countries with large copper mining industries such as Chile and Mongolia (Santiago 2014).

This paper contributes to the literature on biophysical resource quality within this context, by providing a novel data-driven analysis of the influence of copper deposit depth and ore grade on the energy cost of copper ores extraction and concentration. The study is to the author's knowledge the first that provides for a robust statistical analysis of both depth and ore grades for copper resources. In the next subsection, a summary is made of historic studies for energy cost values in copper extraction and processing. The methodology used in the paper is given in "Methodologies and data input" section, including the tested model equations, by-products evaluation and statistical methods. The data inputs are discussed in "Data inputs" section for energy values and their sourcing, the GIS-based analysis of mine-depth for surface mines and the preprocessing of data. The results are presented in "Results" section, and the paper ends with the discussion and conclusions in "Discussion" and "Conclusions" sections, respectively.

\section{Historic Analyses of Energy and Grades of Copper Extraction}

The costs of obtaining a raw mineral and purifying it to a metric ton of product arise from establishing infrastructure, operational inputs, maintenance and transportation costs. The focus lies on operational costs in this paper, which for copper can be tied to different phases within hydro- and pyro-metallurgical technology routes (Davenport et al. 2002; Norgate and Jahanshahi 2010):

- The pyro-metallurgical route for copper can be simplified into three phases: the extraction of the copper holding mineral, the beneficiation to remove unwanted rock or gangue to obtain a $30 \%+$ pure copper concentrate usually via crushing, grinding and flotation and the smelting to a $99 \%+$ copper anode. As a general rule, reductions in particle sizes of $15-20 \mathrm{~mm}$ is referred to as crushing, and further reductions below this size are defined as grinding (Metso 2010). An 
additional electrometallurgical electro-refining step is used for conversion to a $99.99 \%+$ copper cathode.

- The hydrometallurgical route for copper can be simplified into four phases: the extraction of the copper holding mineral which can include the crushing of the mineral typically at the mine-site, the dissolving of copper minerals in an aqueous solution usually by heap leaching using an acid solution, the solvent extraction (or loading) of the copper by an organic solution so as to remove impurities such as iron which remain in the aqueous solution, which also includes the stripping of the copper from the organic solution using an acidic solution resulting in a loaded concentrated strip liquor, and the final electrowinning of the copper to a $99.99 \%+$ copper cathode.

Several variations and combinations of these routes can be found, such as the type of leaching (stockpile, pressure, heap, concentrate), and for the crushing and grinding technology. The process route and technology choice significantly affects energy costs as established in the mining and academic literature, as discussed here and summarized in Table 1. The effects of mining depth on energy inputs were studied by Pitt and Wadsworth (1980) who parametrized a linear model for the energy cost to move a ton of rock across a distance, based on the horizontal length and incline of the mining slope. Their 1970s data for four copper mines in Arizona with an average $0.55 \%$ ore grade yielded 4.6 MJ energy cost added per $\mathrm{kg}$ copper moved for each $100 \mathrm{~m}$ of mining depth. In the study of (Harmsen et al. 2013), a cost value of 2.9 MJ was found for a $100 \mathrm{~m}$ of mining depth, and the weighted average depth was listed at $491 \mathrm{~m}$ for present day copper mines. In general, it has been found that underground mining is more energy intensive than open-cut mining per ton of rock moved. However, because more waste rock is produced in open-pit mining, the per unit of copper energy cost is closer between the two mine-types (Rankin 2011).

Energy inputs effects from ore grades on mining and beneficiation were first studied by Page and Creasey (1975). The study found a mining and beneficiation energy cost of $31.7 \mathrm{MJ} / \mathrm{kg}$ for a $1 \%$ sulfide ore copper mine. More importantly, a stylized power relation was asserted between energy inputs and metric tons of rock processed, based on the notion that declining ore grades imply greater quantities of processed rock per mass of copper. Specific values for mining and crushing were distinguished in Rankin (2011) for a $1 \%$ ore grade open-cut mine. The estimated values were $13.9 \mathrm{MJ} /$ metric ton for mining, 2.5 MJ for crushing. A generalized model was built by Morrell (2004), Morrell (2009), Morrell (2010) for energy costs in crushing grinding based on initial and desired particle size and ore properties validated with observed datasets. The ore grade relation was also evaluated by Marsden (2008) using Freeport-McMoRan operational data from eight copper mines in three countries for processing up to $99.99 \%+$ copper cathode. They established an energy cost for mining, averaged for underground and open-pit operations, at $6.3,13.7$ and $27.4 \mathrm{MJ} / \mathrm{kg}$, and for primary crushing at 0.9 , 1.8 and $3.6 \mathrm{MJ} / \mathrm{kg}$, for ore grades of $1,0.5$ and $0.25 \%$, respectively. The next grinding steps in various circuits were evaluated for the three ore grade levels in ranges of 6.4-10.6 (1\% ore grade), $11.9-21.1$ ( $0.5 \%$ ore grade), 23.9-42.2 ( $0.25 \%$ ore grade). Finally, flotation, re-grinding and tailings disposal energy costs were evaluated at 2, 4.1 and $8.1 \mathrm{MJ} / \mathrm{kg}$, respectively. The relation between ore grades and mine size for copper was examined by Crowson (2003) who found an inverse relation, suggesting that higher costs to mine lower ore grades have been offset by economies of scale in the study period from 1975 to 2000. The discovery of deposits and their ore grades, and the size of deposits and ore grades, was evaluated by Crowson (2012) who found no relationship for these variables over time.

The energy cost of smelting in the pyro-metallurgical route to increase copper purity from $30 \%+$ to $99 \%+$ was evaluated by Pitt and Wadsworth (1980) between 19.9 and $45.3 \mathrm{MJ} / \mathrm{kg}$. Of these values, the widely used flash smelting process found was $20.0-22.4 \mathrm{MJ} / \mathrm{kg}$. The trend in smelting energy costs was established by Coursol et al. (2010) who found a decrease in smelting by a factor 30 since 1900, of which the majority occurred in the first half of the twentieth century. Energy inputs for smelting around the year 2010 were established by the authors at $9.3-12.8 \mathrm{MJ} / \mathrm{kg}$ of $99 \%+$ copper anode including Flash-Flash, ISASMELT, Mitsubishi and Noranda-Teniente technologies. The evaluation in Marsden (2008) found $11.3 \mathrm{MJ} / \mathrm{kg}$ smelting energy. The energy cost of electro-refining was also established at $5.9 \mathrm{MJ} / \mathrm{kg}$ from $99 \%$ a node to $99.99 \%+$ cathode. In Rankin (2011), a value of $3.9 \mathrm{MJ} / \mathrm{kg}$ for electro-refining was provided.

Values for hydrometallurgical concentrating were also estimated in Pitt and Wadsworth (1980) within a range of 25.0 to $78.6 \mathrm{MJ} / \mathrm{kg}$. The value in Rankin (2011) for heap leaching and solvent extraction plus electrowinning (SXEW), was established at $45.5 \mathrm{MJ} / \mathrm{kg}$. The ore grade relation was also evaluated for hydrometallurgy by Marsden (2008) who found heap leaching of 1.1, 2.1 and $4.2 \mathrm{MJ} / \mathrm{kg}$ for ore grades of $1,0.5$ and $0.25 \%$, respectively. Other forms of leaching were established, including concentrate leaching at $6.39 \mathrm{MJ} / \mathrm{kg}$ in a processing setup including prior milling and flotation plus superfine grinding, and runoff-mine leaching at $0.8,1.6$ and $3.2 \mathrm{MJ} / \mathrm{kg}$, for ore grades of $1,0.5$ and $0.25 \%$, respectively. (Marsden 2008) also established values for solvent extraction at $4.6 \mathrm{MJ} / \mathrm{kg}$ and 
Table 1 Summary of copper energy input cost values from the existing literature

\begin{tabular}{|c|c|c|c|}
\hline Component & Energy costs $(\mathrm{MJ} / \mathrm{kg})$ & Ore grade $(\%)$ & Source \\
\hline \multirow[t]{4}{*}{ Mining } & 13.9 & 1.00 & Rankin (2011) \\
\hline & 6.3 & 1.00 & Marsden (2008) \\
\hline & 13.7 & 0.50 & \\
\hline & 27.4 & 0.25 & \\
\hline \multirow[t]{2}{*}{ Mining_per $100 \mathrm{~m}$ of depth } & 4.6 & 0.55 & Pitt and Wadsworth (1980) \\
\hline & 2.9 & - & Harmsen et al. (2013) \\
\hline \multirow[t]{4}{*}{ Crushing } & 2.5 & 1.00 & Rankin (2011) \\
\hline & 0.9 & 1.00 & Marsden (2008) \\
\hline & 1.8 & 0.50 & \\
\hline & 3.6 & 0.25 & \\
\hline \multirow[t]{3}{*}{ Grinding } & $6.4-10.6$ & 1.00 & Marsden (2008) \\
\hline & $11.9-21.1$ & 0.50 & \\
\hline & $23.9-42.2$ & 0.25 & \\
\hline \multirow[t]{3}{*}{ Flotation, re-grinding and tailings disposal } & 2.0 & 1.00 & Marsden (2008) \\
\hline & 4.1 & 0.50 & \\
\hline & 8.1 & 0.25 & \\
\hline \multirow[t]{4}{*}{ Smelting } & $19.9-45.3$ & n.a. & Pitt and Wadsworth (1980) \\
\hline & 10.3 & n.a. & Rankin (2011) \\
\hline & $9.3-12.8$ & n.a. & Coursol et al. (2010) \\
\hline & 11.3 & n.a. & Marsden (2008) \\
\hline \multirow[t]{2}{*}{ Electro-refining } & 5.9 & n.a. & \\
\hline & 3.1 & n.a. & Rankin (2011) \\
\hline \multirow[t]{3}{*}{ Heap leaching } & 1.1 & 1.00 & Marsden (2008) \\
\hline & 2.1 & 0.50 & \\
\hline & 4.2 & 0.25 & \\
\hline Solvent extraction & 4.6 & n.a. & Marsden (2008) \\
\hline Electrowinning & 8.5 & n.a. & \\
\hline Heap leaching + SX-EW & 45.5 & 1.00 & Rankin (2011) \\
\hline \multirow[t]{3}{*}{ Heap leaching including embodied energy } & 103 & 1.00 & Norgate and Jahanshahi (2010) \\
\hline & 179 & 0.50 & \\
\hline & 322 & 0.25 & \\
\hline \multirow{3}{*}{$\begin{array}{l}\text { Beneficiation and smelting including embodied } \\
\text { energy }\end{array}$} & $72-129$ & 1.00 & \\
\hline & $131-244$ & 0.50 & \\
\hline & $249-474$ & 0.25 & \\
\hline \multirow[t]{2}{*}{ Site transport } & $5.3-8.0$ & 0.75 & Chapman and Roberts (1983) in Rankin (2011) \\
\hline & 7.2 & - & Marsden (2008) \\
\hline Product transport & 0.28 & & \\
\hline
\end{tabular}

electrowinning at $8.5 \mathrm{MJ} / \mathrm{kg}$ of copper cathode with no variation for ore grades.

A life cycle analysis-based evaluation was made by Norgate and Jahanshahi (2010), who established values between a 0.1 and $3.0 \%$ ore grade. The values are not directly comparable with the other studies since direct operational + embodied energy was evaluated including supply chain energy requirements to provide for material inputs. The study established an input for beneficiation to a $75-\mu \mathrm{m}$ grinding size plus smelting at 72, 131 and $249 \mathrm{MJ} /$ $\mathrm{kg}$ of copper for $1.0,0.5$ and $0.25 \%$ ore grades, respectively. The evaluation for beneficiation to a $5-\mu \mathrm{m}$ particle size was established at 129, 244 and $474 \mathrm{MJ} / \mathrm{kg}$. The large increase can be explained because substantially more operational inputs such as steel balls in mills and flotation chemicals are used as grinding sizes get smaller; as such, 
the embodied energy also grows. The study also evaluated heap leaching direct and embodied energy inputs at 103 , 179 and $332 \mathrm{MJ} / \mathrm{kg}$, respectively.

Finally, depending on the processing setup substantial transportation costs will be required if the distance from the beneficiation to the smelting $\&$ refining site are substantial. Transport cost for Freeport-McMoRan operations with separated locations was evaluated by Marsden (2008) at 7.2 MJ/kg, versus negligible for close proximity operations. Additional transport costs to bring the copper cathodes to market were evaluated at $0.28 \mathrm{MJ} / \mathrm{kg}$ by Marsden (2008). The evaluation in Rankin (2011) yields a 40-60 MJ cost per ton of rock moved between site operations based on values in Chapman and Roberts (1983), which translates into 5.3-8.0 MJ cost per $\mathrm{kg}$ of copper at a $0.75 \%$ ore grade.

\section{Methodologies and Data Input}

\section{Parsimonious Energy Cost Relation}

The effects of ore grades and mining depth are combined to develop a parsimonious relation to estimate mining and beneficiation energy costs with as few variables as possible. The analysis is carried out from per metric ton of metal produced perspective. As a starting point the relation specified in Page and Creasey (1975) is taken, where the amount of energy $E$, required to mine and concentrate a mineral is reciprocally dependent on a specific head grade, $G$, weighed by $\beta$, i.e., the energy costs to process a metric ton of copper bearing ore. The head grade values are inserted in numerical form. Their relation is specified as:

$E=\alpha+\beta / G$

where $E$ is the processing (by extraction and milling/ flotation or leaching) energy usage in MJ per $\mathrm{kg}$ of copper concentrate at $30 \%+$ purity or copper in pregnant leach solution. The fixed energy cost parameter $\beta$ is divided by an ore grade variable $G$ in percentage of copper per mass of ore extracted, so as to capture changes in energy costs. The parameter $\alpha$ is added as the fixed minimum extraction and processing energy costs.

Equation (1) expresses roughly that ore grades halve the effort to extract doubles and that this scales linearly. It could also be when ore grades decline energy costs will rise at an accelerating rate. This behavior obeys a power law and can be specified as:

$E=\eta \cdot G^{-\varepsilon}$

where energy usage for obtaining concentrate copper in MJ per $\mathrm{kg}$ is based on the ore grade $G$ to the power of a negative parameter $\varepsilon$, and multiplied by a parameter $\eta$, so as to capture accelerating growth in energy costs due to lower ore grades.

A third relation is simplified from the model in Pitt and Wadsworth (1980) as the transport energy cost usage $E$ in MJ per kg of copper moved, being dependent on the vertical distance $D$ from the concentrator at the surface to the deepest mine point weighed by its energy costs. The parameter $\gamma$ captures the effects of depth per meter.

$E=\alpha+\gamma \cdot D$

Again the parameter $\alpha$ is added for the fixed minimum extraction and concentrating energy costs. In the literature, commonly depth is incorporated separately from ore grades (Rankin 2011; Harmsen et al. 2013), which implies that ore grades have limited influence on the degree of rock that has to be lifted, or at least under present circumstances. This assumption is used to functionally add Eqs. (1) and (3) resulting in Eq. (4) and the addition of Eqs. (2) and (3) resulting in Eq. (5). The two Eqs. (4) and (5) enable a combined ore grade and depth evaluation.

$E=\alpha+\gamma \cdot D+\beta / G$

$E=\alpha+\gamma \cdot D+\eta \cdot G^{-\varepsilon}$

The effects of depth $D$ plausibly interact with ore grades $G$, since a lower ore grade implies that more copper bearing rock has to be lifted to a milling or leaching facility. Based on this logic, both the first and third equations are functionally combined, by substitution of parameter $\beta$ and parameter $\eta$ in the right-hand side of Eqs. (1) and (2), respectively, with the right-hand side $\gamma \cdot D$ of Eq. (3), which results in Eqs. (6) and (7) with interaction between depth and ore grade effects on energy costs:

$E=\alpha+\gamma \cdot D / G$

$E=\alpha+\gamma \cdot D \cdot G^{-\varepsilon}$

with extraction energy usage $E$ in $\mathrm{MJ}$ per $\mathrm{kg}$ concentrate copper based on the depth $D$ of mining and ore grade $G$ in percentage of copper per mass of ore. The parameter $\gamma$ now captures the joint effects of both depth and ore grade differences per mine. The equations can be used for total energy inputs or to assert the effect of diesel and electricity individually, in relation to ore grades and depth.

\section{By-Products Evaluation}

The majority of copper mines also produce by-products including molybdenum, gold, silver, zinc and other metals, which affects mine energy cost and financial profits. To establish net-of-by-product energy costs, the by-product energy value for extraction and processing was estimated on a physical basis for each mine. The evaluated byproducts include molybdenum, gold, silver, zinc, lead and 
magnetite. Annual output quantities for these by-products were established either directly from mining company reports or if unavailable based on ore by-product content. Subsequently, output quantities were multiplied by the literature values for energy cost per metric ton included in Table 2. Finally, the by-product energy cost was subtracted for the copper content energy costs. The calculation for byproducts is included in the data spreadsheet supplement B to this paper. As an example of the procedure in the spreadsheet, alongside copper in 2011 the Los Pelambres mine in Chile produced 57.25 metric ton of silver, 1.13 metric ton of gold and 9900 metric ton of molybdenum. The energy inputs estimated for these by-products were 98 , 161 and 158 TJ for silver, gold and molybdenum, respectively. The total sum of $417 \mathrm{TJ}$ was subtracted from total energy inputs of $7047 \mathrm{TJ}$ to establish the net-of-by-product energy cost per metric ton of copper. The calculation was only carried out for total energy since by-product per metric ton energy values were primarily found in the literature on a sum of energy basis.

\section{Statistical Testing Procedure}

The parsimonious relations in the previous section are assessed statistically using a large dataset for copper mines based on the energy costs of mining, concentrating and smelting, the head grade of the extracted ore at the milling stage and the depth of the mine. Data were separated in the analysis between surface mines and underground mines, so as to examine whether there are differences between main mining types. Each of the Eqs. (1), (2), (3) and (4) was tested as outlined in the previous section. The analysis was carried out using linear and nonlinear regression in the $\mathrm{R}$ statistics package. Prior to carrying out the tests, firstly an evaluation of potential outliers was carried out, and secondly, the normality of the data was tested using a Shapiro-Wilk test and a Q-Q plot analysis, as described in "Results" section. Results are reported and evaluated in "Data inputs" section based on whether a null hypothesis of a significant relation is accepted or rejected, the standard error of residuals, a $R^{2}$ goodness-of-fit measure for Eqs. (1), (3), (4), (6), and pseudo- $R^{2}$ for the nonlinear Eqs. (2), (5) and (7), and a correlation between predicted results and sample data values.

\section{Data Inputs}

\section{Energy and Mines}

Fuel, electricity and all input energy data were gathered for 28 copper mining operations operated by companies Anglo-American, Antofagasta, BHP Billiton, CODELCO, China Molybdenum, Lundin Mining, Oz Minerals, Rio Tinto, Sterlite, Grupo Mexico Southern Copper Company, Vedanta and Glencore Xstrata. The observations originated from nine countries, Australia, Chile, Mexico, Peru, Portugal, South Africa, the USA and Zambia. In total, 194 datasets were gathered spanning from 2003 to 2015, including the attributes mine name, mine-type, country, operator, year, processing route, heap grade, mine-depth, energy input, by-products. In case a heap grade value for mined material was not available, the average reserve ore grade value was taken.

The data were organized to enable distinction between four data attributes and their variants for the statistical analysis or pre-/postprocessing:

Table 2 By-product energy cost values used from the existing literature

\begin{tabular}{llll}
\hline By-product & Component & Energy costs $(\mathrm{MJ} / \mathrm{kg})$ & Source \\
\hline Molybdenum & Mining as coproduct & 2.22 & Benavides et al. (2015) \\
& Molybdenum concentration to MoS2 & 13.72 & Benavides et al. (2015) \\
Gold & Mining and milling & 143,000 & Mudd (2007), Norgate and Haque (2012) \\
Silver & Refined silver & 1710 & Rankin (2011) \\
Zinc & Mining & 1.9 & Rankin (2011) \\
& Beneficiation & 3.0 & Rankin (2011) \\
& Mine to Zinc concentrate & 8.1 & This study based on Mt. Isa (Xstrata \\
& & & 2008, 2009, 2010, 2011, 2012) \\
Lead & Mining & 2.0 & Rankin (2011) \\
& Beneficiation & 3.2 & Rankin (2011) \\
& Mine to lead bullion & 8.1 & This study based on Mt. Isa (Xstrata \\
& & & 2008, 2009, 2010, 2011, 2012) \\
Iron & Mining & 0.11 & Rankin (2011) \\
& Beneficiation & 0.45 & Rankin (2011) \\
\hline
\end{tabular}




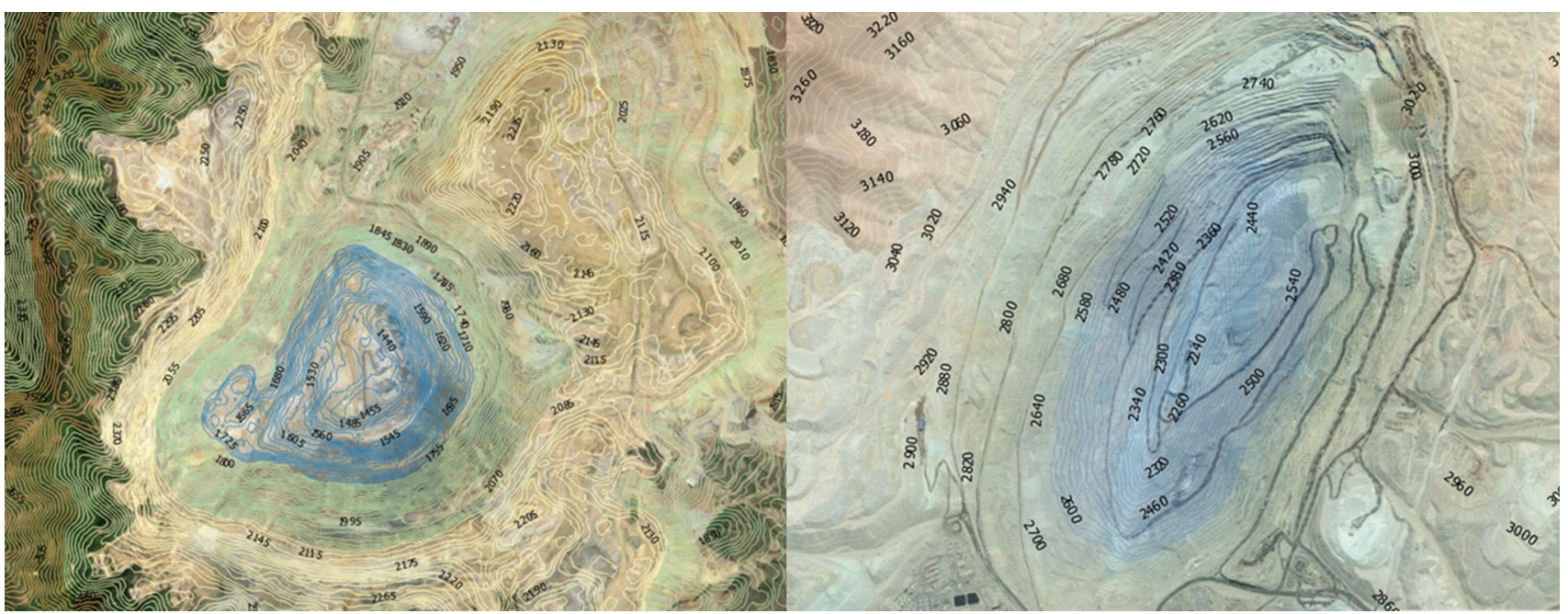

Fig. 1 Contour map examples of Bingham Canyon and Chuquicamata mines

- Mine-type, surface mines (open-pit, open-cut), underground mines (block-caving, sub-level stopping) and sites covering both.

- Deposit type, porphyry, volcanogenic massive sulfide, iron oxide copper gold, metamorphic, stratabound, exotic and carbonatite-hosted magnetite-copper sulfide.

- Processing routes, including mines with pyro-metallurgy to concentrate (milling and flotation), pyrometallurgy to cathode, hydrometallurgy (leaching and SX-EW) and mine-sites with both pyro- and hydrometallurgy routes.

- Produced outputs, mined copper processed, concentrate produced, copper leached, concentrate and leachate processed, anodes, cathodes and rods produced.

After collection, the energy, output and by-products data were translated to a MJ per kg of copper basis by the endproduct point of the mine and gross- and net-of-by-product.

The data were taken from sustainable development reports, company quarterly operational reports, global reporting initiative statements (GRI) (GRI 2013a) and annual reports. In supplement $A$ to this paper, a complete bibliography of the 310 used reports is included organized per company. The entire dataset is given in supplement B.

\section{Mine-Depth}

The height difference between the surface leaching or concentrator facility and the deepest point of the mine-site was estimated to obtain mine-depth. In case of underground mines, the value for the depth of the main mine shaft or mining to transport level was taken. Data were obtained from a mining literature screening for 24 out of 28 mine- sites and GIS contour maps from digital elevation model (DEM) satellite data for 25 mine-sites. In case multiple values were available, from either the literature or satellite data, the data were incorporated in order of the ranking (1) mine schematics with elevation values, (2) mining industry peer-review literature, (3) official company sources, (4) satellite data, (5) other third-party data. The contour maps were generated from one arc-second (30.87-m interval) ASTER GDEM v2 data (NASA 2011). The vertical accuracy of the dataset has been compared against 18,000 geodetic control points and has been found to be within 17-m accuracy at a 95\% confidence level (Tachikawa et al. 2011). To contrast these data, Google Earth utilizes older three arc-second (90-m interval) SRTM v2 data for elevation. The obtained GDEM v2 tiff files were translated into contour maps using QGIS software from which the height difference was visually observed, as shown in Fig. 1 for the Bingham Canyon and Chuquicamata copper mines. The literature mine-depth bibliography and generated contour maps for each mine are added as supplement $\mathrm{C}$ to this paper for reference purposes.

\section{Preprocessing}

Since the objective of the study is to investigate the ore grade- and depth-dependent parts of the copper supply chain, any values for cathodes or anodes were preprocessed to remove smelting, refining, rod and SX-EW energy costs. The value for electro-refining adjustment was $1.12 \mathrm{MJ} / \mathrm{kg}$ based on values for Hindustan copper in TERI (2012), and the adjustment for smelter anodes was carried out based on an averaged $8.8 \mathrm{MJ} / \mathrm{kg}$ smelting cost using data for the Chagres and Tuticorin smelter established from AngloAmerican and Vedanta Sterlite data (see supplement B for 
Fig. 2 Assessment of normality of the datasets using a QQ plot procedure based on standardized residuals of Eqs. (1), (3), (4) and (6)
Table 3 Results of ShapiroWilk analysis of normality (a) Normal Q-Q Plot Equation (1)

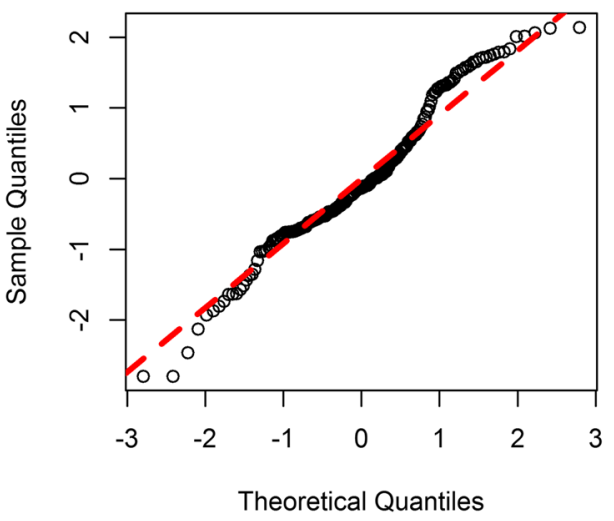

(c) Normal Q-Q Plot Equation (4)

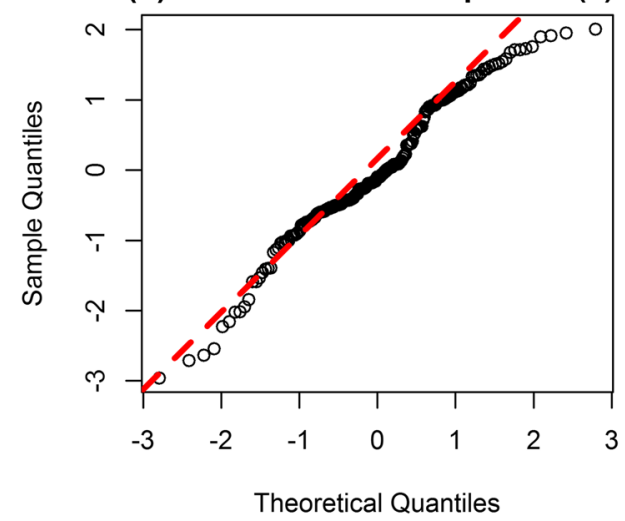

(b) Normal Q-Q Plot Equation (3)

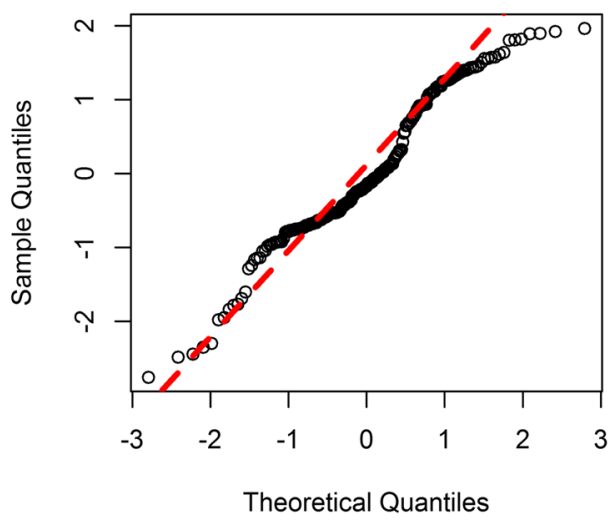

(d) Normal Q-Q Plot Equation (6)

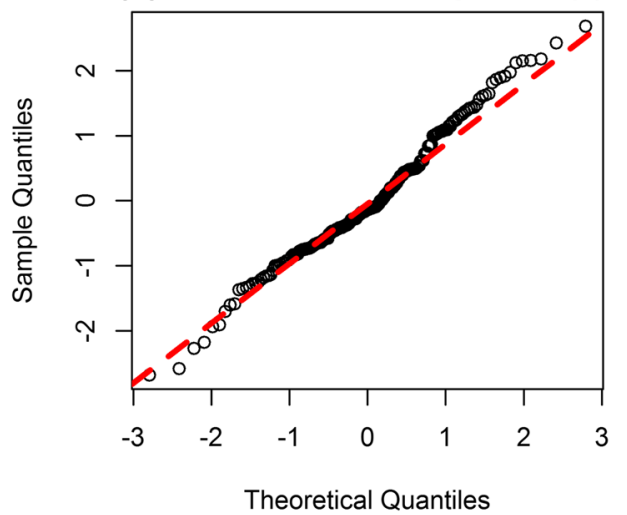

\begin{tabular}{lllll}
\hline Shapiro-Wilk test on standardized residuals & \multicolumn{4}{l}{ Log-linear equations } \\
\cline { 2 - 5 } & $(1)$ & $(3)$ & $(4)$ & $(6)$ \\
\hline Test statistics $W$ & 0.915 & 0.935 & 0.898 & 0.949 \\
$p$ value & 0.011 & 0.18 & 0.002 & 0.095 \\
\hline
\end{tabular}

data adjustment). The values for solvent extraction and electrowinning were taken from (Marsden 2008) at 4.6 and $8.5 \mathrm{MJ} / \mathrm{kg}$, respectively.

The dataset was evaluated for outliers, based on visual inspection of the independent variables head grade and depth to the dependent variable energy costs. The data from the Konkola Copper Mines in Zambia were found to be an extreme outlier, relative to the other data points, and removed from the datasets. The rationale for removal was the high energy costs, despite a $3 \%$ head grade underground mine, to be due to high quantities of water pumped to maintain a dry environment. Pumping volumes are estimated at $400.000 \mathrm{~m}^{3} / \mathrm{day}$, or 365 to $440 \mathrm{~m}^{3} /$ metric ton of copper produced. In contrast, water pumping requirements for other copper mines are a factor ten lower, such as the $1 \%+$ head grade Mount Lyell mine operated by Copper Mines of Tasmania, with 27-35 $\mathrm{m}^{3}$ water pumped per metric ton copper (Vedanta Resources 2010).

After the removal of outliers, additional testing was carried to assess whether the error values of the linear equations were normally distributed, so as to assure validity of the statistical methods. A two-step approach was taken, with as a first step a visual means using a QQ plot wherein the standardized residuals from the empirical data were ranked against the standard normal residuals (Walpole et al. 1998). The data were found not to exhibit a normal distribution in all cases and it was chosen to transform the linear Eqs. (1), (3), (4) and (6) into a loglinear model. The transformed data were found to pass normality, as shown for the 191 value dataset in Fig. 2 and Table 3. 


\section{Results}

\section{Descriptive Data: Ore Grade and Depth}

The mine energy data are summarized in Table 4 for obtaining a copper concentrate via pyro-metallurgy, a pregnant solution via hydrometallurgy, or mines producing both. The values net-of-by-products from mining to product can be summarized as:

- The energy costs for copper concentrate from surface mines were established in a range from 12.7 to 86.9 with a mean of $36.1 \mathrm{MJ} / \mathrm{kg}$. The highest cost values in the range came from the Porphyry deposit Bingham Canyon open-pit mine in the USA with a depth estimate of $900 \mathrm{~m}$ and ore grade average of $0.56 \%$ across the dataset period. In contrast, the lowest cost values were derived from the Porphyry deposit Los Pelambres openpit mine in Chile with a depth estimate of $300 \mathrm{~m}$ and a $0.74 \%$ ore grade average.

- The energy costs for copper concentrate from underground mines were established in a range from 5.7 to 90.6 with a mean of $30.3 \mathrm{MJ} / \mathrm{kg}$. The highest cost values in the range came from the carbonatite-hosted magnetite-copper sulfide deposit Palabora block-cave mine in the USA with a depth estimate of 800-2100 m and ore grade average of $0.66 \%$ across the dataset period. In contrast, the lowest cost values were derived from the volcanogenic massive sulfide deposit Mount Lyell sub-level caving mine in Australia which has a depth estimate of $1000 \mathrm{~m}$ and a $1.21 \%$ ore grade average.

- The energy costs for leaching pregnant solution from surface mines were established in a range from 3.8 to 29.4 with a mean of $14.5 \mathrm{MJ} / \mathrm{kg}$. The highest cost values in the range came from the porphyry deposit Cerro Colorado open-cut mine in Chile with a depth estimate of $230 \mathrm{~m}$ and ore grade average of $0.74 \%$ across the dataset period. In contrast, the lowest cost values were derived from the porphyry deposit Spence open-cut mine in Chile with a depth estimate of $80 \mathrm{~m}$ and a $1.3 \%$ ore grade average.

The values were also established for fuel and electricity cost components. First, a significant difference can be observed between surface and underground mines in case

Table 4 Results from mine energy datasets including preprocessing

\begin{tabular}{|c|c|c|c|c|c|c|c|c|}
\hline \multirow[t]{3}{*}{ Copper output } & \multirow[t]{3}{*}{ Process coverage } & \multirow[t]{3}{*}{ Mine-type } & \multirow{3}{*}{$\begin{array}{l}\text { No. of } \\
\text { datasets }\end{array}$} & \multicolumn{5}{|c|}{ Energy costs (MJ/kg) } \\
\hline & & & & \multicolumn{4}{|c|}{ Gross-of-by-products } & \multirow{2}{*}{$\begin{array}{l}\text { Net-of-by- } \\
\text { products } \\
\text { Total }\end{array}$} \\
\hline & & & & & Fuel & Electricity & Total & \\
\hline \multirow[t]{6}{*}{ Concentrate } & $\begin{array}{l}\text { Mining, crushing, grinding, } \\
\text { flotation }\end{array}$ & Surface & 37 (total) & Range & $4.5-25.4$ & $7.5-25.7$ & $12.5-96.6$ & $12.7-86.9$ \\
\hline & & & $\begin{array}{r}15 \text { (fuel and } \\
\text { electricity) }\end{array}$ & Mean & 11.9 & 12.4 & 40.2 & 36.1 \\
\hline & & Underground & 49 (total) & Range & $0.6-5.5$ & $6.7-20.0$ & $9.3-105.2$ & $5.7-90.6$ \\
\hline & & & $\begin{array}{r}19 \text { (fuel and } \\
\text { electricity) }\end{array}$ & Mean & 4.3 & 14.1 & 33.7 & 30.3 \\
\hline & & Both & 27 (total) & Range & $2.9-40.0$ & $7.0-31.7$ & $12.2-72.7$ & $5.6-66.6$ \\
\hline & & & $\begin{array}{r}18 \text { (fuel and } \\
\text { electricity) }\end{array}$ & Mean & 11.0 & 14.0 & 32.1 & 28.8 \\
\hline \multirow[t]{5}{*}{ Pregnant solution } & Mining, crushing, leaching & Surface & 27 & Range & - & - & $3.9-29.5$ & $3.8-29.4$ \\
\hline & & & & Mean & - & - & 14.6 & 14.5 \\
\hline & & Underground & 0 & & & & & \\
\hline & & Both & 7 & Range & - & - & $14.8-39.8$ & $14.8-39.8$ \\
\hline & & & & Mean & - & - & 29.2 & 29.2 \\
\hline \multirow[t]{5}{*}{$\begin{array}{l}\text { Concentrate }+ \\
\text { pregnant solution }\end{array}$} & $\begin{array}{l}\text { Mining, crushing, grinding, } \\
\text { flotation and leaching }\end{array}$ & Surface & 42 & Range & $3.9-31.4$ & $4.3-15.4$ & $9.6-43.2$ & $9.6-42.2$ \\
\hline & & & & Mean & 12.8 & 9.0 & 21.8 & 20.7 \\
\hline & & Underground & 0 & & & & & \\
\hline & & Both & 5 & Range & $27.5-42.4$ & $28.9-23.7$ & $43.1-66.2$ & $43.1-55.7$ \\
\hline & & & & Mean & 32.7 & 19.5 & 52.2 & 52.2 \\
\hline
\end{tabular}

Value differences between total and sum of fuel and electricity are due to dataset differences caused by preprocessing 
Fig. 3 Three-dimensional plot of energy costs plotted against mine-depth and ore grade data with values for open-pit mines (blue), underground mines (green) and mine-sites with both (red) as well as distinction by processing route pyrometallurgy (circles), hydrometallurgy (triangles) and mine-sites with both processing routes (diamonds) (Color figure online)

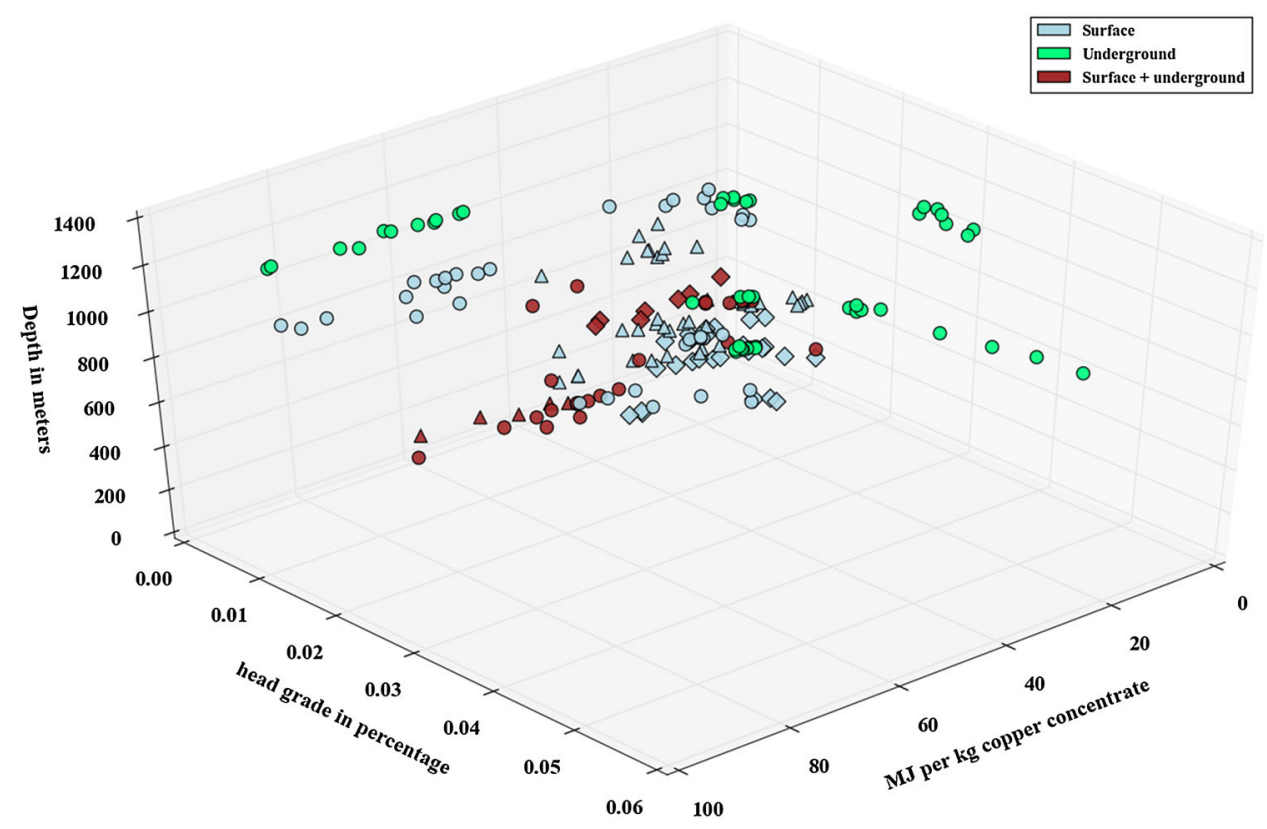

of pyro-metallurgical processing as the latter have much lower fuel inputs. Second, the fuel input difference found between pyro- and hydrometallurgical mines was not found to be substantial, but the electricity input into hydrometallurgical mines was lower.

The values net-of-by-products are also displayed against head grades and depth the three-dimensional plot in Fig. 3. A hyperbolic shape versus head grade values can be observed visually, where energy costs go up rapidly below a $1 \%$ processed head grade, based on observed head grades with a $0.22-4.8 \%$ range with a $1.03 \%$ mean value. The effect of depth appears less pronounced as there are both mines with a depth of $700+\mathrm{m}$ with low energy costs below $20 \mathrm{MJ} / \mathrm{kg}$ and mines with a $700+\mathrm{m}$ depth with $50+\mathrm{MJ} / \mathrm{kg}$ energy values. However, the mines with low energy costs all have head grades above $1 \%$ and vice versa. Moreover, the effect of depth appears to be absent fully for mines with only leaching operations for processing. The depth of mines was found to range between 50 and $1200 \mathrm{~m}$ with a mean of $530 \mathrm{~m}$.

The data for fuel and electricity for produced concentrate from pyro-metallurgy are plotted against head grades and depth and are shown in Fig. 4. The first observation is that electricity usage in $\mathrm{MJ} / \mathrm{kg}$ of concentrate for mines at $200+$ depth levels is larger than diesel use, while the opposite is the case for mines at lower depths. Second, the hyperbolic shape observed earlier can also be discerned on a separate basis for diesel and electricity for copper concentrate.

\section{Statistical Analysis Depth and Ore Grade Effects}

The seven equations as per Sect. 2 were tested for eight different datasets varying by surface or underground mines, and by milling/flotation or heap leaching, as well as analyses for total energy or diesel and electricity both separately. The diesel and electricity tests were only carried out for concentrate and for mixed concentrate + PLS mines, since in case of underground/surface separation too few data points are available for an adequate statistical test. The linear Eqs. (1), (2), (4) and (6) were log-linearly adjusted as described in Sect. 2 .

The full results are added in supplementary materials $\mathrm{D}$ with the results of the best fitted Eq. (4) shown in Table 5 for underground and surface mines, as well as in visual form in Fig. 5. The results can be summarized as follows:

- All data, with the complete 191 point dataset all equations provided a significant result except Eq. (7). The best fit was found for Eq. (5) which provided an $R^{2}$ of 0.37 and a correlation of $61 \%$ with predicted results.

- Surface and underground mines with milling/flotation processing Eqs. (1), (3), (4) and (6) were all significantly below a $5 \%$ significance threshold, with the best result being found for Eqs. (4) and (6). The surface mine dataset yielded a $R^{2}$ of 0.63 and a correlation of $75 \%$ with predicted data for Eq. (4), and for underground mines a $R^{2}$ of 0.84 and a correlation of $97 \%$.

- Mines with leaching only yielded no significant result for any of the equations for neither ore grade nor depth. The depth variation ranges from 50 to $600 \mathrm{~m}$ in the dataset, and the ore grade variation ranges between 0.3 and $1.65 \%$.

- Diesel and electricity with milling/flotation processing showed significant results for diesel with Eqs. (1), (3), (4) and for electricity Eqs. (1), (4) and (6). The best 
Fig. 4 Three-dimensional plot of fuel and electricity energy costs for pyro-metallurgy-based mines plotted against minedepth and ore grade data with values for open-pit mines (blue), underground mines (green) and mine-sites with both (red), as well as distinction by electricity (circles) and diesel (triangles) (Color figure online)

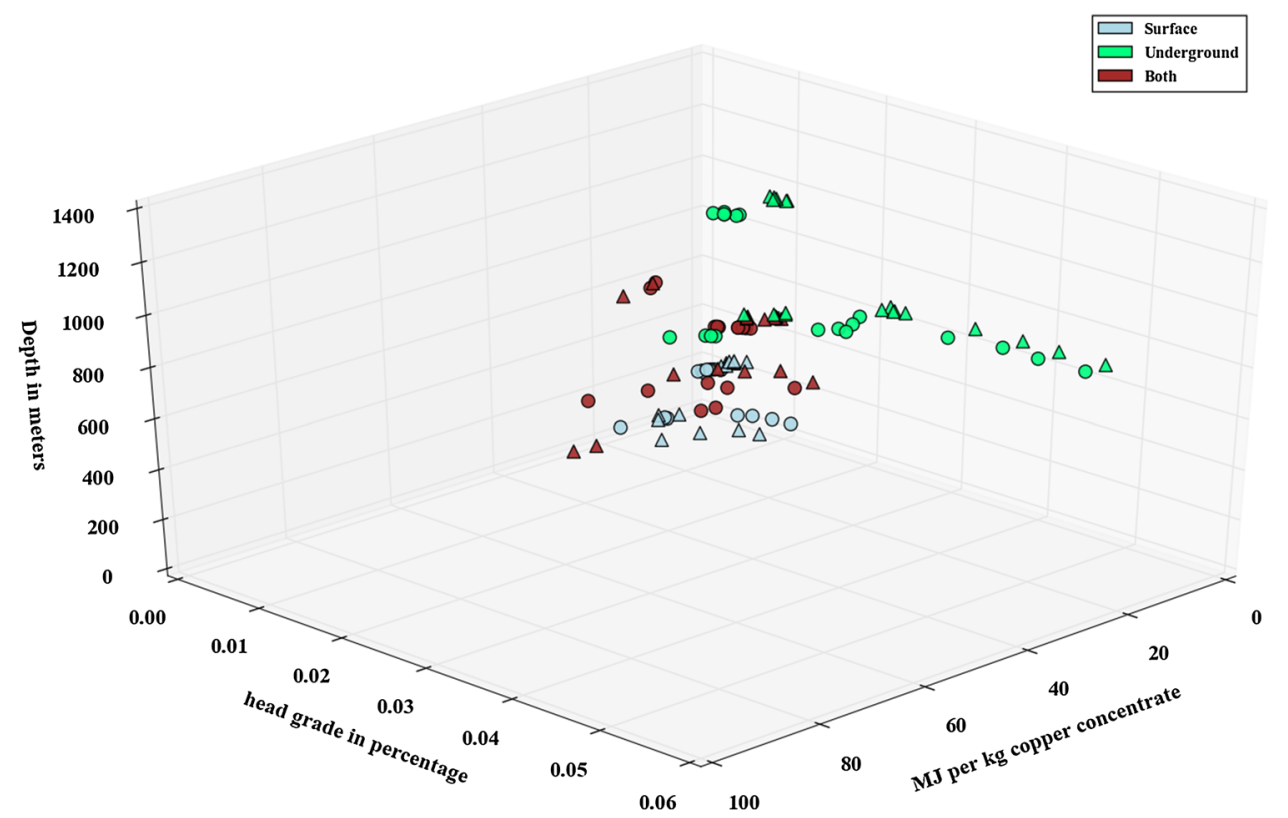

results were found with Eq. (4) with an $R^{2}$ for diesel of 0.23 plus a correlation with predicted values of $46 \%$ and an $R^{2}$ for electricity of 0.45 with correlation of $66 \%$.

- Mines with both milling/flotation and leaching operations showed no significant results for electricity and for diesel significant results for Eqs. (1), (3) and (4). The best result was Eq. (4) with an $R^{2}$ of 0.43 and a correlation of $53 \%$ with predicted values.

The general observation from the results is that combined depth and ore grade models, for mines with milling/ flotation mines, performed better over models with only head grades or depth, showing the value of added information. In case of surface and underground mines with milling/flotation, Eqs. (4) and (6) with combined depth and ore grades have the lowest residual standard error and highest $R^{2}$ values for all three datasets. However, the parameter for depth for the diesel case is negative rendering its influence opposite as expected, although it is positive for electricity The ore grade only Eq. (1) is the only one found suitable for diesel, albeit with low explanatory power.

The key difference between Eqs. (4) and (6) is the lowest standard error of coefficients for Eq. (4) combined with better predictive value for electricity usage. This warrants the first conclusion: Statistically Eq. (4) is the best model for mines with milling/flotation. On the basis of this, an ore grade of $0.5,0.4$ and $0.3 \%$ at $300 \mathrm{~m}$ of depth results in an energy cost of 60,127 and $447 \mathrm{MJ} / \mathrm{kg}$ for underground mines, and 52,95 and $255 \mathrm{MJ} / \mathrm{kg}$ for surface mines, respectively. The second conclusion is that no significant results are found for heap leaching operations where head grade and depth appear to have no direct relation with energy use. The third conclusion is that depth only had a substantial effect on electricity use for mines with milling and flotation operations, with limited influence on diesel usage. The effect is potentially due to the higher electricity needs in underground mining for purposes of haulage by rail and conveyor belts as opposed to trucks. The fourth conclusion is that ore grades have a more significant effect on energy cost for underground mines than surface mines.

\section{Discussion}

\section{Dataset Uncertainty}

The datasets used to evaluate the ore grades and depth impacts were taken from over 14 companies over a decadal time span. Although these analyses are carried out by different teams, the energy data values taken from company sustainability reports are structured using the common global reporting initiative (GRI) for the mining industry (GRI 2013a). For example, the GRI standardises the evaluation of energy data into direct within organization and indirect purchased energy consumed by primary energy source and technology type (GRI 2013b). The second main data uncertainty lies in evaluated mine-depth values, which were taken from various literature sources and 1 arc-second generated mine contour map observations. For 14 out of 20 mines both estimates where available, and it was found that in all 14 cases the depth difference between estimates was within $100 \mathrm{~m}$. The challenge of using this proxy lies in that mine-designs vary substantially especially for underground mines, where mined ore may be lifted down the mine instead of up, for example, in case of El Teniente in 
Table 5 Selection of results for ore grade- and depth-related energy cost models

\begin{tabular}{|c|c|c|c|c|c|c|c|c|c|c|}
\hline Dataset & Eq. nos. & $d f 2$ & $\begin{array}{l}\text { Estimated } \\
\text { parameters }\end{array}$ & $\begin{array}{l}\text { Coeff. } \\
\text { SE }\end{array}$ & $T$-stat & $\operatorname{Pr}(>|t|)$ & $p$ value & $R^{2 *}$ & $\begin{array}{l}\text { Res. } \\
\text { SE }\end{array}$ & $\mathrm{COR} * *$ \\
\hline \multirow{7}{*}{$\begin{array}{l}\text { Surface mine }+ \text { milling/flotation }+ \text { total } \\
\text { energy }\end{array}$} & (1) & 35 & $\alpha=1.547$ & 0.2650 & 5.84 & 0.000 & 0.000 & 0.59 & 0.43 & 0.74 \\
\hline & & & $\beta=0.0129$ & 0.0018 & 7.14 & 0.000 & & & & \\
\hline & (4) & 34 & $\alpha=1.463$ & 0.2619 & 5.59 & 0.000 & 0.000 & 0.63 & 0.41 & 0.75 \\
\hline & & & $\gamma=0.000374$ & 0.0002 & 1.77 & 0.085 & & & & \\
\hline & & & $\beta=0.0119$ & 0.0019 & 6.38 & 0.000 & & & & \\
\hline & (6) & 35 & $\alpha=2.653$ & 0.1414 & 18.70 & 0.000 & 0.000 & 0.51 & 0.47 & 0.79 \\
\hline & & & $\gamma=0.000008$ & 0.0000 & 6.04 & 0.000 & & & & \\
\hline \multirow{7}{*}{$\begin{array}{l}\text { Underground mine }+ \text { milling/flotation }+ \text { total } \\
\text { energy }\end{array}$} & (1) & 44 & $\alpha=1.405$ & 0.1462 & 9.61 & 0.000 & 0.000 & 0.73 & 0.47 & 0.93 \\
\hline & & & $\beta=0.0161$ & 0.0015 & 10.94 & 0.000 & & & & \\
\hline & (4) & 43 & $\alpha=0.820$ & 0.1572 & 5.22 & 0.000 & 0.000 & 0.84 & 0.36 & 0.97 \\
\hline & & & $\gamma=0.00083$ & 0.0002 & 5.41 & 0.000 & & & & \\
\hline & & & $\beta=0.0151$ & 0.0012 & 12.93 & 0.000 & & & & \\
\hline & (6) & 44 & $\alpha=1.88$ & 0.0074 & 25.30 & 0.000 & 0.000 & 0.87 & 0.33 & 0.96 \\
\hline & & & $\gamma=0.000013$ & 0.0000 & 16.84 & 0.000 & & & & \\
\hline \multirow{7}{*}{$\begin{array}{l}\text { Both surface }+ \text { underground }+ \text { milling/ } \\
\text { flotation }+ \text { diesel only }\end{array}$} & (1) & 50 & $\alpha=0.9668$ & 0.2752 & 3.51 & 0.000 & 0.001 & 0.19 & 0.75 & 0.12 \\
\hline & & & $\beta=0.0088$ & 0.0026 & 3.40 & 0.001 & & & & \\
\hline & (3) & 50 & $\alpha=2.429$ & 0.2233 & 10.88 & 0.000 & 0.004 & 0.16 & 0.77 & 0.49 \\
\hline & & & $\gamma=-0.0012$ & 0.0004 & -3.04 & 0.004 & & & & \\
\hline & (4) & 49 & $\alpha=1.564$ & 0.4571 & 3.42 & 0.001 & 0.002 & 0.23 & 0.74 & 0.46 \\
\hline & & & $\gamma=-0.00073$ & 0.0005 & -1.62 & 0.111 & & & & \\
\hline & & & $\beta=0.0064$ & 0.0029 & 2.15 & 0.037 & & & & \\
\hline \multirow{8}{*}{$\begin{array}{l}\text { Both surface }+ \text { underground }+ \text { milling/ } \\
\text { flotation }+ \text { electricity only }\end{array}$} & (1) & 50 & $\alpha=2.109$ & 0.1119 & 18.85 & 0.000 & 0.000 & 0.26 & 0.31 & 0.55 \\
\hline & & & $\beta=0.0044$ & 0.0011 & 4.21 & 0.000 & & & & \\
\hline & (4) & 49 & $\alpha=1.569$ & 0.1649 & 9.51 & 0.000 & 0.000 & 0.45 & 0.27 & 0.66 \\
\hline & & & $\gamma=0.00066$ & 0.0002 & 4.07 & 0.000 & & & & \\
\hline & & & $\beta=0.0067$ & 0.0011 & 6.22 & 0.000 & & & & \\
\hline & (6) & 50 & $\alpha=2.264$ & 0.0089 & 25.20 & 0.000 & 0.001 & 0.20 & 0.32 & 0.38 \\
\hline & & & $\gamma=0.000006$ & 0.0000 & 3.58 & 0.001 & & & & \\
\hline & & & $\gamma=0.00008$ & 0.0000 & 10.32 & 0.000 & & & & \\
\hline
\end{tabular}

* Pseudo- $R^{2}$ is listed using pseudo- $R^{2}=1-$ SSE/SSTOTAL for nonlinear equations

** Correlation between predicted values and empirical values for energy cost of mining and concentrating

${ }^{\text {a }}$ Re-adjusted Eq. (5) without parameter $\eta$ as the original value $f$ was found to be insignificant

Chile, due to its location high above in the mountains. Also mine-depth changes on a gradual basis, whereas in most cases a single depth value was established for multiple years. The other assumption of the height difference is also an oversimplification as mining takes place at various levels in the mine. A rigorous analysis would establish the exact depth/ height, transport distances and transport process (conveyor belt, truck hauling), and how it changes per year, but this was not feasible in the absence of sufficiently detailed data. Nonetheless, the values for mine-depth do provide for an attempt to evaluate the depth effect on mine-types and processing routes.

\section{Validity of Methodology}

The main challenge to the statistical relationship can in view of the authors be made on the extent to which the model relations will remain similar, since they are grounded in current technologies, mine-design and efficiency. The mining industry is well aware of the key role of energy in mining and is involved in significant efforts to reduce these costs where possible. For example, the potential number of meters drilled per hour in underground mining increased from 275 to $450 \mathrm{~m}$ between 2000 and 2005 due to an improved design of the Atlas Copco rocket boomer 
Fig. 5 Data points and Eq. (4) curve related to ore grades at a fixed depth of $450 \mathrm{~m}$ for underground (top right) and surface mines (top left) with milling/flotation in terms of total energy costs and for both mine-types for diesel (bottom $l e f t$ ) and electricity (bottom right)
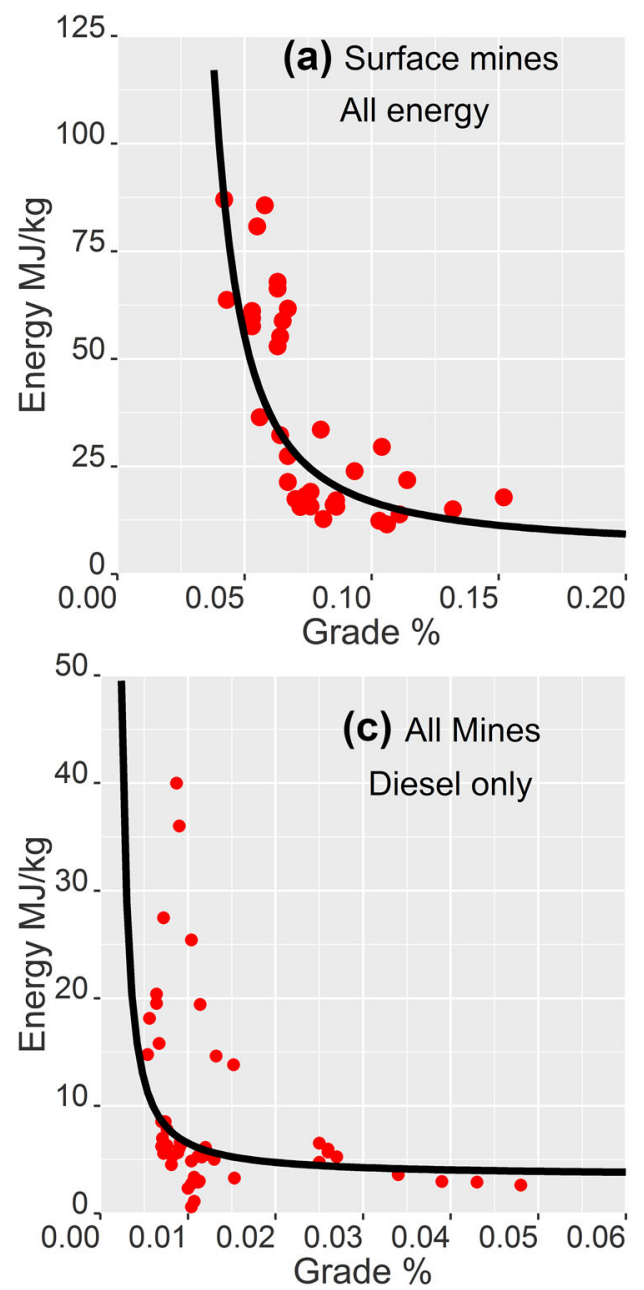

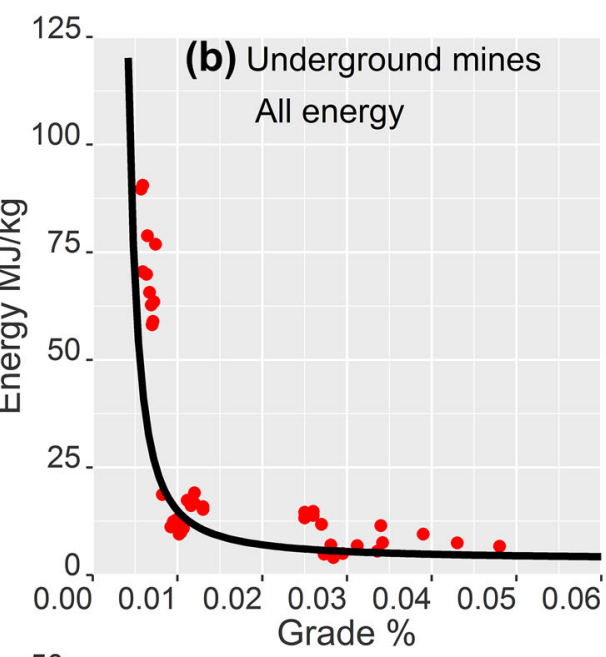

50.

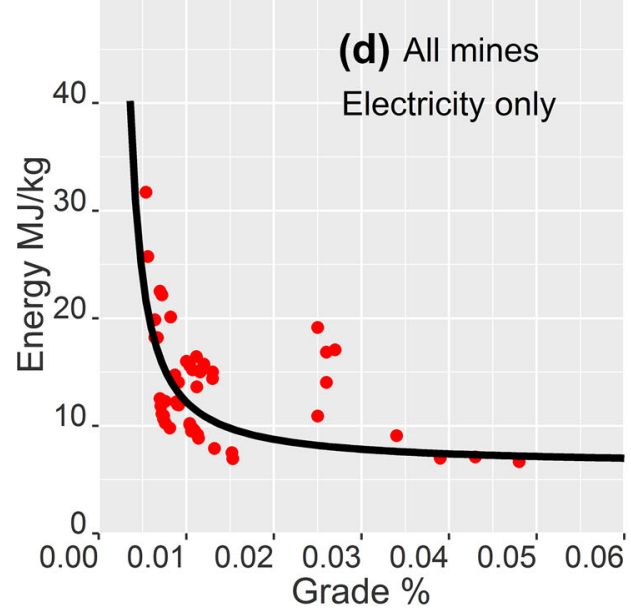

drill machine (Ericcson 2014). And the use of diesel railway haulage is increasingly replaced by electric haulage and belt conveying in underground mining, which has the advantage of reducing energy-intensive underground ventilation needs (Salt and Mears 2006; International Mining 2009). While the technological developments and their implications are well understood in the mining industry, they have to the awareness of the author's not yet been quantified in a precise manner in terms of their historic influence on energy costs. A more precise evaluation of the historic progression in energy efficiency of different mining processes in quantified terms would enhance the meaningfulness of future projection, by substantiation of the validity of relations in the long term of several decades, or lack thereof.

The second key issues with validity lie in the focus on a macro-level of analysis, which limits the ability to dig into the rationale for the results to corroborate the statistical findings, such as mine-designs and specific physical factors at the rock and mineral level for energy costs. These can include among others mine to concentrator or leaching heap distance, mine-water processing route, mine slopes, the particle size of the initial ore, the grinding size after crushing, cutoff grade decisions, the hardness of the ore, the presence of refractory ore and impurities (Hustrulid et al. 2000). While general observations can be made, such as that reliance on electricity increases with deeper mines, a more detailed evaluation would be add to the explanatory power of the found relations (or lack thereof) such as using grind-size effect equations (Morrell 2004, 2010). The level of detail is in view of the authors outside of the scope of this macro-level analysis, as it would warrant a different methodology such as in the form of a physical life cycle mine-simulation model using difference-differential equations and annual mine-planning plus operational decisions.

\section{Interpretation of Results}

The results need to be viewed within the energy boundaries of the analysis, which included direct and indirect energy, and excluded energy use associated with materials used in 
extraction and processing. For example, the steel balls used in milling and the chemicals used in flotation and heap leaching. The lack of an observed relation for leaching to ore grades may be because a substantial portion of the energy comes from material costs due to the chemical nature of the process, as established by Norgate and Jahanshahi (2010) in their life cycle analysis. Another boundary aspect relates to the way electricity is incorporated as final energy, since for macro-level global energy evaluations a comparison at primary energy levels for fossil fuel to electricity conversions is necessary.

In the statistical analysis itself, datasets were not portioned up into mineral deposit types because of too limited groupings for statistical purposes. However, mineral geology can affect energy costs when looking at individual mines. The $\mathrm{Cu}$-stratabound deposit in which the Michilla mine in Chile sits, for instance, has narrow mineral layers which could be of significance in explaining its higher energy costs relative to other heap leaching-based mines in the dataset. Similarly, the sub-level stopping underground mining methods used for the Candelaria mine and Prominent Hill Ankata underground mine may provide for energy cost disadvantages over block-caving mines such as El Teniente, Rio Blanco and Northparkes (Taggart et al. 2012). Other mine-specific factors can include water treatment and pumping needs due to increasing use of desalination such as increasingly the case in copper mines in Chile to several kilometers high, which can easily double water energy costs from conventional water treatment (Zhou and Tol 2005; Jamasmie 2014). Since such mine-specific factors are not taken into account, the results cannot be directly interpreted for individual mines, but should only be interpreted at the general level of copper mining and processing using flotation/milling and heap leaching, with distinctions between surface and underground as well as diesel and electricity usage.

\section{Implications of Results}

The average ore grade of a mining project today is estimated around $0.76 \%$ which for a milling-/flotation-based mine using Eq. (4) translates into an energy cost of 24 and $24.5 \mathrm{MJ} / \mathrm{kg}$ at $450 \mathrm{~m}$ depths for underground and surface mines, respectively. This translates based on the 19.9 million metric tons of copper produced to an energy cost of around 0.84 ExaJoules (about $0.14 \%$ of global 550 ExaJoules energy use), when assuming an additional $18 \mathrm{MJ}$ for smelting/refining and transport (Siirola 2014). The lowest ore grade mine-sites in the dataset include the El Salvador (surface + underground), Bingham Canyon (surface) and Palabora (underground) mines which have ore grades close to $0.5 \%$ in recent years, mine-depths of 150, 900 and $1200 \mathrm{~m}$, and average 2010-2013 energy costs of 47,81 and $93 \mathrm{MJ} / \mathrm{kg}$, respectively. If average ore grades increase to the levels of these mines, energy costs of mining from milling/flotation operations could triple globally. In contrast, the energy costs of scrap copper recycling has been established at 6.3 and $18 \mathrm{MJ} / \mathrm{kg}$ (Grimes et al. 2008; Ashby 2009). However, the referenced studies do not include transport energy requirements to bring scrap copper to the processing plant, and a more complete comparative study of the benefits of recycling versus mining would be a promising avenue of further research.

The upstream cost impacts in copper products can be illustrated by the copper content in a kilometer of low-voltage $0.6 / 1 \mathrm{kV}$ copper cables which is used for underground cabling at street level in local electricity distribution grids in many countries. In the UK, the standard cable is a 3-phase $35 \mathrm{~mm}^{2}$ copper cable, which contains $1750 \mathrm{~kg}$ of copper per $\mathrm{km}$ (Eurocable Group 2011; Scottish Power 2012). The average price of pure copper cathode was 3.1 USD per kg in 2014 (IWG 2016). A cost estimate for $0.6 / 1 \mathrm{kV}$ cables from an Indian manufacturing company in 2014 was retrieved at 32,800 USD per kilometer (LC International 2014). Therefore, the approximate copper content cost proportion is $20 \%$ in a low-voltage cable at retail. Based on data from the Grasberg and Escondida mines, the first and third largest in the world with ore grades above 1.2 and $0.7 \%$, respectively, the energy costs for cathode copper were found to fluctuate between 10 and $15 \%$ before 2003 , and a $15-30 \%$ share between 2007 and 2009 for these two mines (Minera Escondida 2008, 2009, 2010; World Mine Cost Data Exchange 2010a, b). The energy cost of copper wire therefore fell within a $2-6 \%$ range in recent times, which makes energy cost increase impacts on the final product limited yet still relevant when considering high energy prices scenarios. A tripling of energy costs would result in a 4-12\% increase in product prices based on the analysis above. A rise appears to be relatively insignificant, since it is far outweighed by overall energy price fluctuations and their impacts on copper energy mining costs. An integrated analysis of copper energy costs and energy prices scenarios is therefore necessary in the examination of energy cost effects on financial costs of copper products.

At the mine project level, the evaluation of power sourcing is also the key given electricity price impacts. The Australian power mix is at present dominantly coal based and the Chilean consists of hydropower combined with natural gas and coal, both low-cost combinations of electricity. Intermittent solar and wind projects have shattered records in countries with good solar and wind resources in recent years at contract prices of 3 USD cents per $\mathrm{kWh}$ for onshore wind and solar in Morocco and Dubai, respectively (Parkinson 2016; Borgmann 2016). At these price levels, industrial use of solar and wind as power sources is economically feasible. The electricity storage requirements make these sources still too costly though for standalone use, except as "range extenders" of fossil fuel power 
sources. In the foreseeable future, the ability for a copper project to be affordable is therefore highly related to the regional power source and its costs, unless an affordable storage solution for continuous industrial operations emerges which at present is unlikely.

\section{Conclusions}

This study concludes with four summarizing observations drawn from the results and discussion:

- The best explanation for energy costs of mines with milling/flotation processing, for both surface and underground mines, was found in an equation with an interactive effect between depth and ore grades, as opposed to taking these factors as independent.

- The evaluation for mines with milling/flotation found that ore grades had a significant impact on both diesel and electricity use, while in case of depth only electricity was substantial influenced with only limited to no contribution from depth variation. Also it found that ore grade and depth effects are more significant for underground than surface mines.

- Neither ore grades nor depth had a significant influence on energy use for mines that solely utilized leaching operations for extracted ore.

- The impacts on energy costs from mine extraction to concentrate copper from milling/flotation based on the validated log-linear Eq. (4) were found to accelerate significantly at a $0.5 \%$ or lower ore grade (e.g., $>55$ and $67 \mathrm{MJ} / \mathrm{kg}$ for surface and underground, respectively, at $450 \mathrm{~m}$ of depth), which can be interpreted as a biophysical barrier at present technologies below which copper mining extraction using milling/flotation becomes increasingly challenging from a cost perspective.

- The depth impacts on electricity for mines with milling/ flotation were evaluated from the statistically validated log-linear equation at a $7 \%$ increase in copper mining and concentrating electricity costs per $100 \mathrm{~m}$ of minedepth under present technologies.

Open Access This article is distributed under the terms of the Creative Commons Attribution 4.0 International License (http://creative commons.org/licenses/by/4.0/), which permits unrestricted use, distribution, and reproduction in any medium, provided you give appropriate credit to the original author(s) and the source, provide a link to the Creative Commons license, and indicate if changes were made.

\section{References}

Ashby MF (2009) Materials and the environment: eco-informed material choice, 1st edn. Butterworth-Heinemann, Oxford
Bardi U (2013) The mineral question: how energy and technology will determine the future of mining. Front Energy Res 1:9. doi:10.3389/fenrg.2013.00009

Barnett HJ (1979) Scarcity and growth revisited. In: Smith KV (ed) Scarcity and growth reconsidered, 1st edn. John Hopkins University Press, Baltimore

Benavides PT, Dai Q, Sullivan J et al (2015) Material and energy flows associated with select metals in GREET2. Argonne National Laboratory/ESD-15/11

Borgmann M (2016) Dubai shatters all records for cost of solar with earth's largest solar power plant. Apricum, Berlin

Brininstool M (2016) USGS mineral commodity summaries, January 2016: copper. US Geological Survey, VA, pp 54-55

Chapman PF, Roberts F (1983) Metal resources and energy. Butterworth-Heinemann, London, 238 pp. http://www.sciencedir ect.com/science/book/9780408108010

CODELCO (2015) CODELCO update April 2015, p 19

Coursol P, Mackey PJ, Diaz C (2010) Energy consumption in copper sulphide smelting. Proceedings of Copper 2010, Vol. 2Pyrometallurgy I. GDMB, Clausthal-Zellerfeld, pp 649-668

Crowson P (2003) Mine size and the structure of costs. Resour Policy 29:15-36. doi:10.1016/j.resourpol.2004.04.002

Crowson P (2012) Some observations on copper yields and ore grades. Resour Policy 37:59-72. doi:10.1016/j.resourpol.2011. 12.004

Davenport W, King M, Schlesinger M, Biswas A (2002) Extractive metallurgy of copper, 4th edn. Pergamon, Oxford

Emsley J (2001) Nature's building blocks: an A-Z guide to the elements, 1st edn. Oxford University Press, New York

Ericcson M (2014) Supply and demand: innovation drivers in the minerals industry. In: Anderson CG, Dunne RC, Urie JL (eds) Mineral processing and extractive metallurgy, 1st edn. Society for Mining, Metallurgy, and Exploration, Englewood, pp 3-13

Eurocable Group (2011) Product catalog. Jakovlje, Croatia, pp 24-25. http://www.eurocable-group.com/wp-content/uploads/2013/07/ eurocable_group_-_product_catalog_2011.pdf. Accessed 25 Feb 2016

Fuerstenau MC, Jameson GJ, Yoon R-H (2007) Froth flotation: a century of innovation. Society for Mining, Metallurgy, and Exploration, Littleton

GRI (2013a) G4 sector disclosures: mining and metals. Global Reporting Initiative, Amsterdam

GRI (2013b) G4 sustainability reporting guidelines-part 2: implementation manual. Global Reporting Initiative, Amsterdam

Grimes S, Donaldson J, Gomez GC (2008) Report on the environmental benefits of recycling. Bureau of International Recycling, Brussels, $54 \mathrm{pp}$

Hall CAS, Cleveland CJ, Kaufmann R (1986) Energy and resource quality: the ecology of the economic process, 1st edn. Wiley, New York

Harmsen JHM, Roes AL, Patel MK (2013) The impact of copper scarcity on the efficiency of 2050 global renewable energy scenarios. Energy 50:62-73. doi:10.1016/j.energy.2012.12.006

Hustrulid WA, McCarter MK, Van Zyl DJA (2000) Slope stability in surface mining, 1st edn. Society for Mining, Metallurgy, and Exploration, Littleton

International Mining (2009) The El Teniente conundrum. InfoMine, pp 62-63

IWG (2016) Omega-Camden copper base price. http://www. iwgcopper.com/price-history?year=2015. Accessed 25 Feb 2016

Jamasmie C (2014) Chile set to make mining desalination mandatory. http://www.mining.com/chile-set-to-make-mining-desalinationmandatory-57150/. Accessed 18 July 2016

Kerr RA (2014) The coming copper peak. Science 343:722-724. doi:10.1126/science.343.6172.722 
Layton M, Fu Y, Currie J (2015) Metal detector: China copper to aluminium substitution set to accelerate. Goldman Sachs Global Investment Research, New York

LC International (2014) Price list effective from 1st July 2014. http:// www.lccables.com/armd.html. Accessed 26 Feb 2016

Marsden JO (2008) Energy efficiency and copper hydrometallurgy. In: Young CA, Taylor PR, Anderson CG, Choi Y (eds) Hydrometallurgy 2000: proceedings of the sixth international symposium. Society for Mining, Metallurgy, and Exploration, Colorado

Metso (2010) Basics in minerals processing. Metso Corporation, Helsinki, 354 pp. http://bit.ly/2g8JADl. Accessed 11 July 2016

Minera Escondida (2008) Escondida financial statements 2007. Antofagasta

Minera Escondida (2009) Financial statements 2008. Antofagasta

Minera Escondida (2010) Estados Financieros 2009. Antofagasta

Morrell S (2004) An alternative energy-size relationship to that proposed by Bond for the design and optimisation of grinding circuits. Int J Miner Process 74:133-141. doi:10.1016/j.minpro. 2003.10.002

Morrell S (2009) Predicting the overall specific energy requirement of crushing, high pressure grinding roll and tumbling mill circuits. Miner Eng 22:544-549. doi:10.1016/j.mineng.2009.01.005

Morrell S (2010) Predicting the specific energy required for size reduction of relatively coarse feeds in conventional crushers and high pressure grinding rolls. Miner Eng 23:151-153. doi:10. 1016/j.mineng.2009.10.003

Mudd GM (2007) An analysis of historic production trends in Australian base metal mining. Ore Geol Rev 32(1-2):227-261

Mudd GM (2009) Historical trends in base metal mining: backcasting to understand the sustainability of mining. In: 48th annual conference metal, pp 1-10

Mudd GM, Weng Z, Jowitt SM (2013) Assessment of global Cu resource trends and endowments. Econ Geol 108:1163-1183

NASA (2011) ASTER - advanced spaceborne thermal emission and elevation map announcement. https://asterweb.jpl.nasa.gov/ gdem.asp

Norgate T, Hague N (2012) Using life cycle assessment to evaluate some environmental impacts of gold production. J Cleaner Prod 29-30:53-63

Norgate T, Jahanshahi S (2010) Low grade ores-smelt, leach or concentrate? Miner Eng 23:65-73. doi:10.1016/j.mineng.2009. 10.002

Page NJ, Creasey SC (1975) Ore grade, metal production, and energy. J Res US Geol Surv 3:9-13

Parkinson G (2016) New low for wind energy costs: morocco tender averages USD30/MWh. In: REneweconomy. http://renewecon omy.com.au/2016/new-low-for-wind-energy-costs-morocco-ten der-averages-us30mwh-81108
Pitt CH, Wadsworth ME (1980) An assesment of energy requirements in proven and new copper processes. Idaho Falls

Rankin WJ (2011) Minerals, metals and sustainability: meeting future material needs, 1st edn. CSIRO Publishing, Collingwood

Salt T, Mears K (2006) Automation gets the most out of mining railway infrastructure. Railw. Gaz

Santiago GL (2014) Energy in Chile: winds of change. Econ

Scottish Power (2012) ScottishPower distribution cables \& equipment: metal theft. http://www.spenergynetworks.co.uk/userfiles/ file/scottishpower_cables_equipment_metal_theft.pdf. Accessed 26 Feb 2016

Siirola JJ (2014) Speculations on global energy demand and supply going forward. Curr Opin Chem Eng 5:96-100. doi:10.1016/j. coche.2014.07.002

Tachikawa T, Kaku M, Iwasaki A et al (2011) ASTER global digital elevation model version 2-summary of validation results. https:// pubs.er.usgs.gov/publication/70005960. Accessed 15 July 2016

Taggart P, Slifirski M, Shillaker M et al (2012) Block caving with Rio and NCM. Credit Suisse Equity Research, Zurich, $31 \mathrm{pp}$

TERI (2012) Widening the coverage of PAT scheme: sectoral manual - copper industry. New Delhi, $57 \mathrm{pp}$

Tilton JE, Lagos G (2007) Assessing the long-run availability of copper. Resour Policy 32:19-23. doi:10.1016/j.resourpol.2007. 04.001

U.S. Congress-Office of Technology Assessment (1988) Copper: technology and competitiveness. Washington

USGS (2014) USGS Data series 140: Copper Statistics U.S. Geological Survey 1900-2013

Vedanta Resources (2010) Vedanta sustainable development report 2009

Walpole R, Myers RH, Myers SL (1998) Probability and statistics for engineers and scientists, 6th edn. Prentice-Hall, Upper Saddle River

World Mine Cost Data Exchange (2010a) Grasberg Minecost Model

World Mine Cost Data Exchange (2010b) Escondida Minecost Model

Xstrata (2008) Xstrata Zinc North Queensland Sustainability Report 2007. Mount Isa, QLD, 34 pp

Xstrata (2009) Xstrata Zinc North Queensland Sustainability Report 2008. Mount Isa, QLD, $50 \mathrm{pp}$

Xstrata (2010) Xstrata Zinc Australia Sustainability Report 2009. Brisbane, QLD, $50 \mathrm{pp}$

Xstrata (2011) Xstrata Zinc Australia Sustainability Report 2010. Brisbane, QLD, $49 \mathrm{pp}$

Xstrata (2012) Xstrata Zinc Australia Sustainability Report 2011. Brisbane, QLD, $51 \mathrm{pp}$

Zhou Y, Tol RSJ (2005) Evaluating the costs of desalination and water transport. Water Resour Res 41:1-10. doi:10.1029/ 2004WR003749 